\title{
Vida de Professores de Educação Física: o pessoal e o profissional no exercício da docência
}

\author{
Núbia Zorzanelli dos Santos* \\ Valter Bracht ${ }^{* *}$ \\ Felipe Quintão de Almeida***
}

\begin{abstract}
Resumo: Este artigo trata do ciclo de vida de três professores de educação física no contexto escolar, numa análise que combina elementos biográficos com aqueles relacionados à carreira profissional. Investiga questões referentes à formação dos professores, desde suas experiências escolares na infância e adolescência até o posterior itinerário profissional em educação física. Finaliza apontando algumas consequências para a formação docente.
\end{abstract}

Palavras-chave: Biografia como assunto. Docentes: história. Prática profissional. Educação Física.

\section{INTRODUÇÃO}

Nos últimos anos, alguns pesquisadores têm chamado a atenção para a dificuldade de se materializar na intervenção os avanços teóricos alcançados na educação física escolar brasileira (MUÑOZ PALAFOX, 2002; CAPARROZ; BRACHT, 2007). A explicação mais corrente consiste em atribuir ao professor a responsabilidade por essa dificuldade, desconsiderando-se os muitos fatores, não apenas profissionais que emperram as ações na direção de uma prática renovada. Insatisfeitos com esse tipo de compreensão que culpa a figura do professor e eterniza a metáfora do "professor-bola", 1 realizamos

\footnotetext{
"Licenciada em Educação Física no CEFD. Universidade Federal do Espírito Santo, Vitória, ES, Brasil. E-mail: biasz_914@hotmail.com

* Pesquisador LESEF/CEFD. Universidade Federal do Espírito Santo, Vitória, ES, Brasil. Doutor pela Universidade de Oldenburg (Alemanha). E-mail: valter.bracht@pesquisador.cnpq.br

** LESEF/CEFD e Núcleo de Estudos e Pesquisas Educação e Sociedade Contemporânea. Doutorando em Educação no Programa de Pós-Graduação em Educação da Universidade Federal de Santa Catarina, Florianópolis, SC, Brasil. E-mail: fqalmeida@hotmail.com

${ }^{1}$ A expressão "professor-bola" refere-se àquele professor cuja principal ou única ação em aula resume-se a entregar a bola (ou outro material) aos seus alunos.
} 
uma investigação com o objetivo de compreender a evolução da pessoa que é professor, nas suas relações com a carreira, com o saber e consigo mesmo. Para tanto, tomamos sua formação de modo bastante amplo, desde as experiências escolares na infância e adolescência, passando pela opção e entrada na habilitação profissional, até o afastamento ou a aposentadoria (BUENO, 2002; BOLÍVAR, 2002). Seguimos também Goodson (1995) em sua estratégia de evitar uma incidência direta e predominante sobre a prática docente, por considerá-la o aspecto mais exposto e problemático do mundo dos professores (nos casos em que isso acontece, é como se o professor fosse a própria prática). Tal incidência deveria ser complementada, pelo menos parcialmente, com uma consideração mais lata sobre a vida do professor. A razão para assumirmos essa direção é que, quando os professores discorrem sobre seu desenvolvimento profissional, e veremos isso neste artigo, eles constantemente trazem à tona informações sobre suas próprias vidas nos seus aspectos extraprofissionais. Isso pode ser assumido como prova razoável de que os próprios professores consideram esses elementos da maior relevância.

Durante muito tempo, contudo, os investigadores em educação consideraram as narrativas dos professores, suas vozes, como elementos irrelevantes de pesquisa e formação. Reduziu-se a profissão docente a um conjunto de competências e capacidades vinculadas à prática, realçando a dimensão essencialmente técnica da ação pedagógica, seus melhores métodos e técnicas. Essa visão do professor provocou uma forte separação entre sua vida pessoal e profissional, sendo um dos principais fatores responsáveis, como apontou Nóvoa (1997, p. 17), por sua crise identitária: os estudos que “[...] cruzam a nossa maneira de ser com a nossa maneira de ensinar e desvendam na nossa maneira de ensinar a nossa maneira de ser" somente vão ganhar visível impulso no Brasil em meados da década de $1990,{ }^{2}$ momento a partir do qual nossa bibliografia pedagógica, ao reabilitar a presença do sujeito no cenário educacional (JOSSO, 2004), foi "invadida" por obras e estudos sobre a vida dos professores, as carreiras

${ }^{2}$ No âmbito da educação física, merece destaque, nesse sentido, o pioneirismo de Borges (1998).

Movimento, Porto Alegre, v. 15, n. 02, p. 141-165, abril/junho de 2009. 
e os percursos profissionais, as (auto)biografias docentes ou o desenvolvimento pessoal do professores. ${ }^{3}$

O recurso ao ciclo de vida (pessoal e profissional) dos professores é um aspecto de uma metodologia que, como solicitava Goodson (1995) em texto clássico, permite ouvir a voz dos professores. Em nossa investigação, as vozes escutadas são de três professores de educação física que, há mais de 20 anos, dedicam considerável tempo de sua vida a essa profissão na escola. Trata-se das professoras Orquídea e Amor-Perfeito (essa aposentada há 13 anos) e do professor Girassol. ${ }^{4} \mathrm{Na}$ pesquisa, optamos pelas entrevistas biográficas orais (SOUZA, 2003) com os supracitados professores. O desafio da entrevista biográfica é fazer emergir um mínimo de ordem da experiência existencial. Antes da realização das entrevistas, que assumiram um caráter semiestruturado para valorizar e explorar a riqueza das histórias narradas por nossos informantes, foi estabelecido um contato prévio e pessoal com os professores-colaboradores (na própria escola na qual trabalham) em que ficou esclarecido o objetivo deste estudo e a forma como eles poderiam contribuir, concedendo uma ou mais entrevistas cujos eixos norteadores combinariam aspectos de sua vida pessoal com aqueles relacionados à sua carreira profissional. ${ }^{5}$ Esse emprego,

\footnotetext{
${ }^{3}$ Uma descrição detalhada do desenvolvimento, dos usos e das apropriações dessa tendência recente no Brasil pode ser obtida em Bueno et al. (2006). Uma peculiaridade do caso brasileiro, como apontam essas autoras, é que a perspectiva da pesquisa/formação defendida por autores "precursores" da história de vida em formação ou dos métodos (auto)biográficos, tais como Gaston Pineau, Pierre Dominicé e Marie-Christine Josso, Christine Delory-Momberger, etc., teve pouca ressonância entre nós. Nós últimos anos, entretanto, tais autores tiveram seus livros traduzidos para o português, bem como seus textos também são mais divulgados no Brasil. Sintomático dessa situação é o fato de a revista Educação e Pesquisa ter publicado, em 2006, uma seção em torno do tema história de vida e formação, publicando textos daqueles pesquisadores. No âmbito da educação física, conforme já pontuaram Molina Neto et al. (2006), ainda é pequena a ocorrência de artigos que adotam histórias de vida ou narrativas (auto)biográficas de professores(as) como referencial teórico-metodológico de investigação.

${ }^{4}$ Nomes fictícios, para não permitir a identificação dos professores.

${ }^{5} \mathrm{~A}$ entrevista foi realizada em dois momentos, dada sua extensão. As conversas informais, na escola e em outros espaços fora da instituição, foram também bastante úteis. Como essa pesquisa se insere no contexto de outra investigação que emprega estratégias vinculadas às pesquisas com biografias e/ou histórias de vida de professores (BRACHT, 2007), estamos combinando, na continuidade da investigação, as entrevistas biográficas orais com outros instrumentos de análise, notadamente a observação participante nas escolas (devidamente registrada em um diário de campo, em filmagens e fotos), com a análise de documentos produzidos pelos professores e pela escola, oportunidade para melhor acessar outras informações da vida do professor e de seu trabalho.
}

Movimento, Porto Alegre, v. 15, n. 02, p. 141-165, abril/junho de 2009. 
conforme a tipologia de Nóvoa (1995), pautou-se por uma preocupação essencialmente investigativa, com o objetivo de obter conhecimento sobre aspectos da formação dos referidos docentes e suas práticas pedagógicas. Acertamos também que, após as entrevistas, os professores teriam acesso ao conteúdo transcrito (o que não demorou a acontecer), bem como iriam receber o relatório de pesquisa construído com a ajuda deles, o que aconteceu alguns meses depois. Para a escolha das histórias de vida a serem ouvidas, estabelecemos como critérios: (a) os professores deveriam estar há pelo menos dez anos exercendo a profissão; (b) o fato de que seria interessante trabalhar com algum professor que já estivesse aposentado, dado o menor número de trabalhos que exploram o ciclo de vida de exprofessores (BUENO, 2002).

Nos três itens seguintes, apresentamos uma síntese sobre as entrevistas biográficas realizadas, finalizando com algumas consequências para a formação docente.

\section{A VIDA QUE ANTECEDE E SUCEDE À HABILTAÇÃO PROFISSIONAL}

Podemos depreender, das narrativas biográficas aqui recolhidas, que a decisão por qual profissão seguir é resultado do encontro de um conjunto de fatores culturais e sociais que, aliados às condições subjetivas, constituem a própria vida em construção. No caso de nossos três professores-colaboradores, notamos como esse conjunto de fatores originou motivações diversas para a escolha da profissão. Em relação à professora Amor Perfeito, o fator financeiro constituiu um elemento duplamente determinante na decisão de sua carreira profissional. Primeiro, porque a falta de dinheiro a impossibilitou de cursar Medicina, habilitação por ela desejada inicialmente. Depois porque, ainda graças a esse motivo, se dizia excluída por suas professoras na escola em que estudava:

[...] os professores da época, apesar deles terem estudos, eles faziam comparações, quando escolhiam alunos para participarem de alguma coisa, só participavam aquelas crianças que tinham mais condições, não é condição de roupa, não, é aquele mais bonitinho,

Movimento, Porto Alegre, v. 15, n. 02, p. 141-165, abril/junho de 2009. 
que tinha as coisas direitinhas em casa, eram escolhidos, e a gente ficava sempre na retaguarda. Aí, então, eu falei: 'um dia eu vou ser professora e vou tratar todo mundo igual'. Aí fiz o magistério, terminei meu ginásio, fiz meu magistério. Aí fui trabalhar com o ensino fundamental, aí logo eu troquei para a educação física e me dei muito bem, porque era o que eu queria. E, quando eu passei a fazer educação física, dar aulas, aí, então, eu fiz tudo que eu tinha vontade de fazer, que os professores não fizeram por mim (AMOR-PERFEITO).

O argumento de Orquídea e Girassol para a escolha da docência em educação física é o mais comum entre os profissionais da área: a paixão pelos esportes e o envolvimento com ele antes mesmo da entrada na universidade. No caso de ambos, a incerteza, normalmente associada à decisão por qual profissão seguir, foi amenizada já que ambos optaram por uma área que, além de familiar, estava relacionada à realização pessoal dos dois e às suas histórias de vida:

\begin{abstract}
Sempre gostei muito de esporte, principalmente a dança, a dança que me levou à opção da educação física. Eu dançava, fazia balé (ORQUÍDEA).

[...] inicialmente a expectativa era: 'vou fazer um curso que está ligado ao que eu gosto de fazer, praticar esporte, viajar, essas coisas todas'. [...] Primeiro gostar de praticar esporte, sempre gostei, em toda a minha vida, mas, no fundo, no fundo mesmo, fazer o curso de educação física não estava previsto na minha cabeça. Apareceu assim: um amigo meu chegou, eu morava em Colatina e eu estava lá de bobeira. Aí falou: 'Estou chegando lá de Vitória e fiz minha inscrição para o curso de educação física'. Aí deu aquele estalo [...] curso de educação física. Eu gostava de esporte, pratico, viajo pro interior de Colatina pra apitar um jogo ou organizar uma competição dentro de Colatina, eu vivo com isso, então, de repente, né, era a luz que faltava, era o toque (GIRASSOL).
\end{abstract}

Essas experiências de vida anteriores ao ingresso na universidade são também importantes para se entender por que os três professores, apesar de estudarem na mesma instituição universitária (entre

Movimento, Porto Alegre, v. 15, n. 02, p. 141-165, abril/junho de 2009. 
meados da década de 1970 e início da década posterior), têm avaliações distintas da formação recebida. A professora Orquídea não gostou do curso, devido ao caráter altamente desportivizante do mesmo:

[...] quando eu entrei, eu fiquei um pouco decepcionada, porque eu entrei com uma expectativa e, quando você chega lá dentro, é outra, porque o que acontecia, as provas eram dadas como, é... Basquete... Dez cestas, se eu fizesse as dez cestas, eu tinha a nota dez; se eu fizesse duas, eu tinha a nota dois. Então isso aí começou a me desestimular um pouco, porque eles não estavam me preparando para dar aula e eles estavam querendo que eu fosse uma atleta e não era isso que eu queria (ORQUÍDEA).

A professora Amor-Perfeito adorou o curso exatamente pelo seu caráter prático-desportivo: “[...] nós tínhamos, na época, os melhores professores na educação física, inclusive a UFES era a melhor escola, a melhor universidade de educação física de todas". Para o professor Girassol, o curso apenas veio ratificar aquilo que ele já vivenciava antes mesmo de entrar no curso de habilitação profissional. Após a entrada no curso, "[...] fui me interessando mais, e isso só veio a contribuir para eu ter uma maior valorização do que eu já fazia enquanto atleta, que era a prática de esporte sistematizado, organizado" (GIRASSOL).

Esses relatos demonstram que as experiências sociais, culturais e corporais de Girassol, Orquídea e Amor-Perfeito, cuja origem remonta suas histórias de vida, são determinantes na escolha profissional e posterior envolvimento no curso, sendo forte o suficiente para, em muitos casos, não sofrerem modificações durante a permanência na formação universitária. Além disso, atuam como modeladores das práticas pedagógicas levadas a efeito pelos professores já "formados", uma vez que tais experiências não desaparecem da história do sujeito em formação (TARDIF, 2000; FIGUEIREDO, 2004). São esses filtros, por exemplo, que permitiram à professora Amor-Perfeito, antes mesmo de trocar o magistério (como professora primária) pela educação física, fazer "[...] algumas coisas na escola. Quando precisava, dava umas dancinhas e esses negócios. Eu já me metia, mas não dava aula mesmo, aí, quando eu me formei, que eu fiz a troca". Em

Movimento, Porto Alegre, v. 15, n. 02, p. 141-165, abril/junho de 2009. 
Girassol, tais saberes da experiência também são visíveis em suas recordações escolares:

$$
\begin{aligned}
& \text { É meus professores, não professores da UFES, profes- } \\
& \text { sores das escolas que estudei, tentei copiar algumas } \\
& \text { coisas deles, o que achava de interessante de cada } \\
& \text { um, o que eu via que era interessante em termos de } \\
& \text { organização, de metodologia de dar aula, depois co- } \\
& \text { mecei a fazer comparação: 'Ah, fulano fazia assim'. } \\
& \text { E, às vezes, dessa forma é melhor [...]. }
\end{aligned}
$$

Além da habilitação profissional, dado o seu caráter escolarizado, privilegiar os saberes acadêmicos em detrimento daqueles que trazem de suas histórias de vida, na escola, na família, nos clubes etc., nossos professores são também categóricos ao afirmar que essa mesma formação é distante daquilo que acontece nos cotidianos escolares. Essa é uma constatação, diga-se de passagem, comum não só às narrativas de Girassol, Amor-Perfeito e Orquídea, mas também a relatos contidos em outros estudos (BRACHT et al., 2003; BORGES, 1998; ALMEIDA; FENSTERSEIFER, 2007; FIGUEIREDO, 2004; SANTINI; MOLINA NETO, 2005). A consequência disso é óbvia: os professores se sentem despreparados para o exercício profissional, já que há um hiato enorme entre aquilo que acontece nos cursos de formação e a prática pedagógica. Toma lugar, assim, a ideia de que as habilidades pedagógicas dos professores decorrem das experiências diretas da sala de aula, bem expressa na tese tantas vezes ouvida segundo a qual "a teoria na prática é outra".

Tal distanciamento (e os equívocos dele resultantes) não é privilégio da formação para a habilitação profissional, reproduzindo-se também na formação continuada. Muitos autores em educação física têm chamado a atenção para a ineficácia desse tipo de formação, quando deslocada do local de trabalho e das questões que afligem o professor como pessoa. Não é diferente nos testemunhos de Amor-Perfeito, Orquídea e Girassol. Reproduz-se, na formação em serviço dos três, uma lógica de desvalorização das experiências e vozes da pessoa que é professor, seja porque a formação recebida é muito teórica (Girassol) ou desvinculada das questões específicas do ensino (AmorPerfeito), seja porque funciona conforme a lógica do professor especialista (Orquídea).

Movimento, Porto Alegre, v. 15, n. 02, p. 141-165, abril/junho de 2009. 


\section{ESTRATÉGIAS PARA PRESERVAÇÃO DA VIDA NO TRABALHO: ENTRE O DIÁLOGO, A NEGOCIAÇÃO E A DOENÇA}

Nos últimos anos, foram publicados inúmeros trabalhos em educação e educação física escolar que discutem os processos que provocam distúrbios generalizados na vida do professor. Alguns autores os têm caracterizado como síndrome de Burnout (CODO, 1999) ou mal-estar docente (ESTEVE, 1999), enquanto outros, particularmente na educação física, os denominam síndrome do esgotamento profissional (SANTINI, 2004, 2005 et al.; SANTINI; MOLINA NETO, 2005). Nos relatos biográficos fornecidos por Girassol, Orquídea e Amor-Perfeito, são mencionadas as múltiplas causas desencadeadoras dessa síndrome em professores de educação física. Dentre elas, ficou bastante evidenciada, nas vozes aqui escutadas: a) uma mudança radical na relação entre professor e aluno, dada pelo fato de hoje os alunos não respeitarem mais a autoridade do professor, dirigindo ao mestre de outrora agressões de toda ordem, sem que, na prática, funcionem os mecanismos de arbitragem existentes (gerando insegurança no trabalho); b) a desresponsabilização da família na educação dos filhos, imputando à escola e aos professores responsabilidades educativas que, tradicionalmente, eram assumidas na esfera familiar. O resultado desse acúmulo de funções é o desajustamento dos professores relativamente ao significado e ao alcance do seu trabalho. Lutando em várias frentes e realizando uma atividade fragmentária, sua identidade profissional vê-se seriamente comprometida pela multiplicidade de funções, não raro contraditórias entre si (BOLÍVAR, 2002), conforme demonstram os seus depoimentos.

Os professores buscam solucionar essas situações adversas no trabalho (que podem produzir neles estados doentios), já que, nas palavras de Girassol, todo esse clima desfavorável não é nada “[...] que te imobilize no seu trabalho. É até desafios que a gente vai lançando. A gente vê o que pode mudar [...]”. Para tanto, eles criam estratégias que, além do ensino, garantem a preservação da vida (sua saúde) no exercício da profissão. Como Santini et al. (2003) explicam, o professor tem que alterar a postura de condução de suas aulas

Movimento, Porto Alegre, v. 15, n. 02, p. 141-165, abril/junho de 2009. 
a fim de que possa exercer o controle disciplinar sobre os alunos, estabelecendo essa medida com o propósito de complementar as exigências da tarefa docente e de "sobrevivência" no trabalho. Segundo fizeram questão de destacar Amor-Perfeito, Girassol e Orquídea, a melhor saída para os problemas que enfrentam no dia-a-dia, com os alunos ou com os colegas de profissão, é o diálogo. Ouvir o que o aluno tem a dizer, suas histórias, aconselhá-los, mostrar-lhes outras possibilidades, não tachá-los gratuitamente de vagabundos, são atitudes que podem ser visualizadas em seus depoimentos. Leiamos a emblemática passagem da professora Amor-Perfeito:

[...] não tive atrito nenhum com eles, porque esses meninos, esses alunos, você precisa ser amiga deles e eles confiar em você, porque, se você entrar de sola com eles. 'Ah você é vagabundo! Você é não sei o quê!' Aí pega, né? Eles ficam irritados, ficam revoltados, aí é a hora que eles querem pegar professor, levar armas para escola, mas não tive problema com nenhum não, nem eu nem a outra professora. A gente contornava bonitinho lá fora com eles. Não tive problemas com eles, eles tinham problemas na sala de aula, mas, na minha aula e na aula da outra professora, a gente não tinha problema. Aceitavam [minha aula], conversava muito com eles, ria, e eles falavam uma linguagem a gente falava também com eles, fazia aquela bagunça e acabava cativando.

Quando o diálogo já não dava conta de garantir o processo de ensino, a negociação com os alunos também se mostrou uma estratégia profícua para nossos professores:

[...] Então a gente partiu agora para discussão em grupo, as aulas têm que ocorrer dessa forma: a gente pode estar deixando vocês fazerem alguma atividade diferenciada, que é justamente o que eles gostam, de fazer futebol, tanto menina quanto menino, futebol, queimada. Então, para você não ficar só tomando cacetada na cabeça, então você negocia isso, no início. Que você consegue negociar isso, vai colocando devagar e, de repente, no ano seguinte, você já controlou a turma, você já mostrou [que] essa é uma aula interessante, vale estar participando melhor [...]. E acaba

Movimento, Porto Alegre, v. 15, n. 02, p. 141-165, abril/junho de 2009. 
negociando depois o que você entende como aula. Inicialmente, quando você chega na escola, você negocia o que eles querem, mas impõe o que você quer também (GIRASSOL).

Apelar para a negociação é uma solução também presente no depoimento da professora Orquídea:

[...] eu não bato de frente com eles. Às vezes, eu falo bem assim: "Oh, hoje eu vou dar uma aula minha, mas, na próxima aula, eu prometo que vai ser de vocês". Então, a gente negocia. Só assim que você consegue alguma coisa, porque, senão você não consegue.

Em muitas ocasiões, contudo, a professora relata que não conseguia convencer os alunos da importância da aula, sendo suas estratégias (negociação e diálogo) incapazes de persuadir os alunos do contrário. O resultado desse processo, dia após dia, foi a desmotivação com o trabalho:

[...] então eles [os alunos/alunas] têm resistência, só querem fazer aquilo que eles querem, então isso te desmotiva um pouco. Às vezes, você planeja uma aula e você não consegue fazer aquilo, então o que vai acontecendo? Você vai largando pra lá, você vai deixando que o seu planejamento quem vai fazendo são eles no dia-a-dia. Principalmente $7^{\mathrm{a}}$ e $8^{\mathrm{a}}$, tá? E eu não tenho mais esse gás pra ficar insistindo não, tá? Às vezes, eu falo pra eles bem assim: 'oh, meu salário está lá, todo final de mês, e eu estou aqui, vocês não me cobram nada, então eu não faço nada. Quem está perdendo sou eu? Não, são vocês'. A gente tenta jogar umas coisas assim, né? Mas não adianta, não. É sempre a mesma coisa, eles querem recrear, eles moram nesse morro, então o que acontece? Aí não tem espaço pra eles e o único espaço que eles têm é na aula de educação física. [Eles] trabalham. Então eles querem bola, eu vou tirar a razão deles? De repente, eu não tiro a razão deles, não. É por isso que eles gostam de educação física. Vê se eles gostam de matemática e de português? Não gostam.

Seu depoimento mostra uma professora já exaurida emocionalmente, devido aos desgastes diários a que é submetida na escola,

Movimento, Porto Alegre, v. 15, n. 02, p. 141-165, abril/junho de 2009. 
especialmente com os discentes. Segundo informações de pessoas próximas à Orquídea na instituição em que leciona, em 2007, ela se afastou por três vezes para resolver problemas relacionados à saúde que estariam associados às dificuldades que enfrenta no trabalho. $\mathrm{O}$ resultado desse quadro é péssimo para a vida da professora: "Oh, hoje eu não tenho muito mais prazer, não, tá? Eu vou confessar para você: não tenho mais aquele gás que eu tinha antes, não. Não tenho mais mesmo" (ORQUÍDEA). Em situações como a sua, o docente realiza mal seu trabalho, acomodando-se "[...] então o que vai acontecendo? Você vai largando pra lá [...]", no sentido de proteger sua própria imagem e manter sua vida sob controle, tendo, por seu turno, que "[...] suportar a crítica generalizada, que, sem analisar essas circunstâncias, os considera como responsáveis imediatos pelas falhas do sistema de ensino" (ESTEVE, 1995, p. 97). O fracasso, desse modo, personaliza-se na figura do professor: "Se tudo corre bem, os pais pensam que os filhos são bons estudantes. Se as coisas correm mal, pensam que os professores são maus profissionais" (ESTEVE, 1995, p. 105).

Como disseram Lapo e Bueno (2003), analisando outro contexto, os professores mostram-se mais preocupados em despender suas energias em defesa própria (um conformismo vinculado à sua estratégia de sobrevivência no ensino) do que abertos a novas experiências e aprendizagens. Na bibliografia, procura-se caracterizar esse distanciamento das obrigações básicas no ensino com o nome de absenteísmo ou abandono do trabalho docente (LAPO; BUENO, 2003; ESTEVE, 1999; GONZALEZ; FENSTERSEIFER, 2006), um fenômeno que, e a despeito das iniciativas dos professores na direção oposta, pode ter sido consequência dos inúmeros dissabores que envolvem os docentes hoje na profissão (tão visíveis nas narrativas aqui recolhidas, em especial na de Orquídea).

\section{ESTÁGIOS NA PROFISSÃO DOCENTE: AS CARREIRAS DE GIRASSOL, ORQUÍDEA E AMOR PERFEITO EM FOCO}

Paralela à valorização da vida como chave de leitura que permite acessar aspectos até então pouco valorizados da formação e

Movimento, Porto Alegre, v. 15, n. 02, p. 141-165, abril/junho de 2009. 
da atuação de professores, nos últimos anos, tem-se empregado a noção de carreira profissional como uma maneira de entender a evolução profissional dos professores. Trata-se do caso de estudar o percurso da vida em uma estrutura organizativa e compreender como as características da pessoa, ao influenciarem tal organização, são, ao mesmo tempo, influenciadas por ela. No Brasil, talvez o exemplo mais conhecido e empregado dessa tendência seja a classificação elaborada por Huberman (1995). Sem perder de vista seu caráter ideal, e atento à dinamicidade da vida profissional de cada professor aqui estudado, foi possível identificar, como Huberman (1995) apontou em seu estudo, que o início da docência propriamente dita foi um período nevrálgico na carreira dos professores aqui investigados. Esse é o momento da chamada "sobrevivência" ou "choque com o real", o confronto entre o que se aprende nos cursos de formação e a realidade encontrada nas escolas, um período de intensa aprendizagem (quase sempre do tipo ensaio-erro), de dificuldades com os alunos, com material didático inadequado. A professora Amor-Perfeito assim se reporta a esse período de sua carreira:

\begin{abstract}
No início, quando a gente pega ginásio, a gente está saindo, então tem alguma coisa que dá problema, por exemplo, vôlei, eu aprendi, mas não aprendi muito como deveria ser, para trabalhar com o aluno. Então eu tive aquele choque, mas assim fui aprendendo com os próprios alunos, que eles sabiam, então eu, quietinha ali, eu dava aula, mas fui aprendendo com eles. No início, eu aprendi mais com os alunos do que eu mesmo pra falar com eles. Mas foi do jeito que me passaram, né? Sempre fica [a formação inicial] a desejar, sempre fica uma matéria a desejar, e, no meu caso, foi o vôlei.
\end{abstract}

A professora Orquídea relata as dificuldades iniciais encontradas e suas maneiras de resolvê-las:

[...] porque eles saíam correndo, correndo igual uns doidos, rodando a escola, e eu gritando, aí aquilo eu não conseguia saber o que eu fazia, porque eu fiquei assim, eu me senti desesperada um pouco, mas eu fui entendendo aquela situação.

Movimento, Porto Alegre, v. 15, n. 02, p. 141-165, abril/junho de 2009. 
Até pegar o "jeito", todavia, "[...] chorei muito em casa, chegava em casa chorava, chorava, pensava: 'meu Deus, eu não aprendi nada na faculdade, o que eu vou fazer [...]'. Aí que foi o choque entre o que é falado e o real". Quando perguntamos se era capaz de descriminar os "melhores" e os "piores" anos de sua carreira, ela declarou:

\begin{abstract}
Olha, os piores foram os primeiros, tá? Por causa do choque, é um aprendizado, você vai aprender a dar aula. E os melhores foram, assim, mais ou menos do segundo ao terceiro ano em diante que eu entrei, eu acho que foram os melhores. Agora está sendo os piores de uns cinco anos pra trás, no meio, é ótimo. Deixa eu completar, é, por exemplo, porque hoje está pior, não é porque eu já estou perto de me aposentar, porque eu sou superativa, eu sou uma pessoa que não consigo parar, eu falo muito. Já deu para perceber, né? Então é isso, não me desgasta, o meu trabalho não me desgasta, ele me realiza até. Agora, o que me desgasta são os alunos (ORQUÍDEA).
\end{abstract}

No discurso da professora Orquídea, observamos a descrição de seus "melhores" e "piores" momentos no exercício da profissão na forma de fases:

\begin{abstract}
A fase do choque, a fase da tranquilidade. Que aí veio e pronto. Aí eu me senti segura, né? Aí pronto, aí foi tranquilo. Aí depois veio uma fase assim, meio de medo. É, de uns cinco anos pra cá, a gente sente um pouco de receio, porque você não pode chamar a atenção de um aluno mais, entendeu? Então você tem que ter muito jeito, saber como conversar, tem que saber como chegar a esse aluno, entendeu?
\end{abstract}

Os depoimentos das professoras Orquídea e Amor-Perfeito confirmam uma tese comum nos estudos sobre o desenvolvimento da carreira profissional na docência, que "[...] indicam a eventual ocorrência dos piores anos da carreira no início da vida profissional [...]" (GONÇALVES, 1995, p. 154). A fase da tranquilidade a que Orquídea se remete relaciona-se àquilo que Huberman (1995) denomina de fase de estabilização, de mais empenho, de decisão de seus objetivos, de consolidação e aperfeiçoamento de seu plano pedagógico,

Movimento, Porto Alegre, v. 15, n. 02, p. 141-165, abril/junho de 2009. 
de melhor domínio, que vem juntamente com a sensação de libertação, de segurança, de descontração. Nessa fase, os docentes conseguem lidar melhor com situações inusitadas, deixam-se conduzir e explorar mais a ponto de a autoridade tornar-se mais natural.

Em relação ao professor Girassol, é interessante perceber que ele, à semelhança de Orquídea, também recorre às fases ou momentos para caracterizar sua carreira profissional. Assim ele se expressa sobre o início da vida profissional:

\begin{abstract}
É fase de adaptação, você formou e começa a fazer com que as pessoas acreditem que você é um bom profissional. '[...] será que eu vou atender a necessidade que essa pessoa tem?'. [...] Você tem que fazer as pessoas acreditarem no seu trabalho [...]. Você está ali nos primeiros cinco, dez anos de sua vida batalhando, correndo atrás, com disposição de estar ajudando e tudo mais. Depois vem uma fase de busca, de querer fazer mais coisas, você precisa fazer com que eles reconheçam. O que de repente você descobriu que de repente precisa. Aquela escola precisa de uma academia de dança ali dentro, ou que você pode fazer aquilo, festas dentro da escola, junina, dia do estudante, não sei o quê. Se vai ficar legal, se deslumbra com aquilo e, de repente, hoje você tá numa fase de acomodação, mas não de estar acomodado [...]
\end{abstract}

No caso do professor Girassol, além dessa fase estabilizadora ou adaptativa, como ele chama, podemos identificar também um desejo de diversificar seu trabalho (HUBERMAN, 1995), um momento em que você quer fazer mais coisas, modificando o ensino para os alunos (ainda que ele vincule isso à necessidade de reconhecimento na instituição), assumindo novas frentes de trabalho, enfim, maximizando sua atuação na escola. Nessa etapa, portanto, os professores mostram-se mais motivados e empenhados no que diz respeito ao âmbito escolar e tal disposição se traduz e pode vir acompanhada da ambição pessoal: a procura de mais autoridade, responsabilidade e prestígio diante dos outros. Seu reconhecimento definitivo na instituição! A fase de acomodação a que ele (professor Girassol) se refere, e que, em sua opinião, não deve ser entendida como uma situação de

Movimento, Porto Alegre, v. 15, n. 02, p. 141-165, abril/junho de 2009. 
abandono do trabalho docente propriamente dito, constitui uma espécie de recompensa por tanto esforço e trabalho dedicado à carreira e à escola. Se buscarmos o correlato desse comentário no modelo de Huberman (1995), isso que Girassol chama de acomodação corresponde ao estágio da carreira em que o nível de ambição e investimento decresce, enquanto a sensação de confiança e de serenidade aumenta.

\begin{abstract}
As pessoas nada mais têm a provar, aos outros ou a si próprias; reduzem a distância que separam os objectivos do início da carreira daquilo que foi possível conseguir até ao momento, apresentando em termos mais modestos as metas a alcançar em anos futuros (HUBERMAN, 1995, p. 44).
\end{abstract}

É muito interessante perceber que essa caracterização (ideal) presente na bibliografia guarda semelhança com o que disse Girassol a respeito dessa fase:

[...] acomodação é o seguinte: eu já sei quem eu sou, já mostrei para as pessoas o quanto eu sou capaz e agora eu estou usufruindo isso e colocando, estou fazendo as coisas com mais tranquilidade, com mais saber, né?

Não devemos perder de vista, contudo, que a satisfação de sabermos o que estamos fazendo, acreditando que se estamos fazendo bem, confunde-se, por vezes, com uma certa dose de conservadorismo (GONÇALVES, 1995). Ou, então, como lembra-nos Morgado (2005), embora a estabilidade seja muito necessária, quando se converte na lógica dominante da organização da docência, pode desencadear imobilidade, protecionismo e medo da desordem em detrimento dos fatores positivos com ela relacionados (o sentimento de pertença, certeza, clareza, comodidade, ordem etc.).

Ainda conforme Huberman (1995), os docentes chegam a um determinado estágio da carreira em que começam a questionar o que fizeram de sua vida profissional. Eles, literalmente, põem em questão o trabalho efetuado até então, comparam as realizações efetivadas e as que "deveriam ter" acontecido, em suma, refletem sobre a imagem que têm de si mesmos como professores. O depoimento de Orquídea é revelador:

Movimento, Porto Alegre, v. 15, n. 02, p. 141-165, abril/junho de 2009. 
[...] a minha imagem de hoje? Você quer que faça um retrato meu de hoje? Como profissional? Você quer uma autoavaliação minha? Eu digo mesmo, uma autoavaliação minha hoje. Eu acho que hoje eu sou uma merda! [risos] Porque eu digo mesmo eu não estou conseguindo alcançar aquilo que eu sempre consegui. Então, não sou eu que não estou sendo capaz, são eles [alunos] que não tão mais me respondendo aquilo que eu queria. Então com isso você se frustra um pouco. Aí então chega o ponto final de carreira, é o pior que tem. Não é porque você está cansado, é pela situação também, porque como eu estou desestimulada de uns cinco anos pra cá. Eu falo para todo mundo que está entrando na escola que eu tenho pena deles, porque vocês, no caso, vocês não vão se aposentar na profissão de vocês, porque vocês não vão aguentar, entendeu? Porque eu tenho pena. Vocês não vão aguentar! Vocês já estão entrando numa fase terrível, entendeu? Eu já tô no final da minha fase, agora vocês estão começando. Tudo bem que vocês estão cheios de gás, mas só que isso não é tudo.

No testemunho da professora Orquídea (inclusive direcionado ao professor entrevistador), observamos um sentimento de inutilidade em relação ao trabalho que realiza e a frustração pela incapacidade de levar à prática os seus ideais pedagógicos nessa fase da carreira, que ela própria caracteriza como no final. Não surpreende que ela esteja ávida pela aposentadoria:

Não estou vendo o tempinho para passar isso logo. [...] Em 2010, está chegando. Pertinho. [...] Por isso tudo que eu terminei de te falar, a gente chega num ponto muito desgastante da educação física, não só da educação física, mas de todas as matérias. Não é reclamação só minha. Quando a gente senta, que faz reunião de professores, é de outras áreas também. Não vou nem colocar só a educação física, a reclamação é a mesma, sabe? Está todo mundo desgostoso, está todo mundo esgotado. Nós estamos praticamente ainda no meio do ano e está parecendo que a gente está no final do ano. Está todo mundo cansado. Mas o cansaço é devido a quê? Ao comportamento dos alunos, isso deixa a gente muito estressado.

Movimento, Porto Alegre, v. 15, n. 02, p. 141-165, abril/junho de 2009. 
A identidade é um lugar de lutas e conflitos, um espaço de construção de maneiras de ser e de estar na profissão, como cada um se sente e se diz professor (uma estilística da existência vivida pelo professor de maneira própria). Em relação ao professor Girassol, a imagem que ele tem de si próprio na profissão é a de uma pessoa consciente e profissional, que se esforça para fazer o melhor possível para seus alunos:

Eu me vejo um cara muito humano em relação ao aluno, tento respeitar o máximo para que ele me respeite. Não imponho as coisas, eu direciono para o entendimento que aquilo ali é importante. [...]. Então me vejo, acredito, posso colocar uma suposição assim, um bom profissional.

Mesmo se considerando um bom profissional, ele testemunha:

Algumas considerações aí na minha vida, que abalou a minha forma de dar aula. Algum problema particular meu. Eu construí, dentro de uma escola municipal, uma escolinha de esportes, e eu acreditava que, trabalhando em conjunto com a escola, poderia estar tendo um ganho para essa garotada, que era manutenção através da Prefeitura, de ela estar absorvendo essa escolinha e dando suporte financeiro, ajuda de custo, merenda. Para eu fazer a Prefeitura acreditar, eu tinha que estar investindo um dinheiro próprio, e eu acabei tirando muito dinheiro particular meu, e não via retorno, aí, quando eu não vi esse retorno, eu comecei a ficar preocupado e comecei a ficar pensando muito mesmo, deixando as aulas de lado, relaxei um pouquinho. Tinha até um período que eu estava achando, ainda hoje eu ainda não absorvi isso, não, achando a minha aula de 0 a 10 , não estava chegando a 5. Ela tinha um patamar bem maior. Hoje já melhorou um pouquinho, já superei bastante, mas ainda não está dentro daquilo que eu acreditava que tinha que estar. Tipo assim, de 8 pra 9 , de 9 pra 10 , para eu passar de 8 pra 10 , eu ainda não cheguei lá. Já subi uns dois pontos, dois pontos não, até mais, era menos de 5 , já devo estar chegando aos 7 , dentro da avaliação que eu tenho.

No relato do professor, observa-se o desânimo e o sentimento de frustração com o fato ocorrido: “[...] essa situação da escolinha

Movimento, Porto Alegre, v. 15, n. 02, p. 141-165, abril/junho de 2009. 
que não deu certo, fui bem claro, tentei, fiz por onde, o arrependimento não é a nível profissional, é a nível pessoal, porque eu investi numa coisa pessoal e não tive retorno" (GIRASSOL). O docente trabalha abaixo do seu potencial, abaixo do que ele próprio acredita ser o ideal, e essa transformação é decorrente da não realização de desejos pessoais no âmbito profissional. Esse depoimento demonstra como o pessoal e o profissional estão imbricados, uma vez que não há como separar o professor da pessoa e a pessoa do professor (JOSSO, 2004).

No que diz respeito à identidade profissional da professora Amor-Perfeito, a avaliação positiva de seu percurso na carreira é reflexo de sua história de vida em formação (JOSSO, 2004), já que, malgrado aquela frustração de menina na escola, sua biografia educativa é recheada de momentos que expressam satisfação no trabalho. Nem mesmo a aproximação do fim da carreira foi capaz de abalar sua disposição para o trabalho (e aqui seu depoimento contraria aqueles estudos que afirmam ser o final da carreira um dos piores na carreira docente). Não surpreende, desse modo, sua avaliação como professora: "Eu tenho uma imagem excelente, me sinto realizada" (AMOR-PERFEITO). Compreendemos, por que ela afirma: “[...] finalizei com prazer, porque a gente aposenta, depois dá uma vontade de voltar". E foi exatamente o que ela fez: ao se aposentar, em 1994, após 25 anos e oito meses de profissão, atuou por mais três anos como professora da rede estadual de ensino, desta vez, por contrato de designação temporária (dt), até parar em definitivo, devido ao cansaço:

\begin{abstract}
Me chamaram, mas aí eu já estava cansada de trabalhar. No sol, né? Porque, na época, também não tinha cobertura nas quadras. Olha minhas manchinhas de sol! Agora que está numa boa, botaram cobertura, depois que eu saí cheia de mancha... Mas foi bom (AMOR-PERFEITO).
\end{abstract}

Ainda assim, longe das escolas, destaca que as principais atividades de sua vida estão relacionadas com a atuação profissional que exerceu por tantos anos. Diz ela:

Movimento, Porto Alegre, v. 15, n. 02, p. 141-165, abril/junho de 2009. 
[...] sempre faço algo que esteja vinculada à educação física, eu continuo participando da ginástica para $3^{\mathrm{a}}$ idade, continuo ajudando quando precisa ir a algum passeio com a $3^{\mathrm{a}}$ idade, aí sempre tem um onibuzinho pra me levar com elas, aí eu brinco dentro do ônibus com elas, então minha vida é toda mesmo na educação física.

O professor Girassol, à semelhança de Amor-Perfeito, também fornece indícios de como o final da carreira não é necessariamente marcado por um pessimismo generalizado ou por reclamações de toda ordem (muitas com razão, decerto). Ambos fazem questão de destacar, em seus depoimentos, a importância do trabalho em suas vidas pessoais, "um momento de se construir amizades inesquecíveis", de "grandes aprendizagens", de "reconhecimento pessoal", o que desperta neles a sensação de, como sumariza Girassol, "Vou levar tudo isso pra mim":

Oh, eu não queria aposentar, não. Sou obrigado por lei, né? Trinta anos, mas eu acredito que eu tenho mais 30 anos para trabalhar ainda. Adoro o que eu faço, sabe? Então, você me perguntou agorinha mesmo, né? Se eu faço alguma coisa fora daqui, se eu paro de trabalhar aqui eu vou fazer o quê? Ficar em casa? É gostoso ficar em casa, mas falta alguma coisa, falta você ouvir o garoto ficar xingando, gritando, dando parabéns para você, morrendo de rir, chorando, o colega conversar na escola (professor Girassol).

\section{CONSIDERAÇÕES FINAIS}

Este trabalho não teve qualquer pretensão de generalizar as evidências biográficas e profissionais aqui narradas. Nossa expectativa foi compreender, de um ponto de vista biográfico, o desenvolvimento de três vidas (Girassol, Amor-Perfeito e Orquídea) na profissão. Entendemos que as decisões relativas à escolha da profissão, a direção que é dada à carreira, o desinvestimento no ensino, as experiências curriculares inovadoras, o abandono da docência, os momentos críticos pelos quais passam na carreira, as perspectivas futuras etc. poderiam ser convenientemente estudados e compreendidos melhor se, além dos

Movimento, Porto Alegre, v. 15, n. 02, p. 141-165, abril/junho de 2009. 
aspectos eminentemente profissionais, atentássemos também à pessoa que é o professor. Do que foi aqui sintetizado, e levando-se em conta o debate já acumulado no campo, gostaríamos de concluir com alguns apontamentos que derivam e ao mesmo tempo extrapolam o trabalho, se configurando como desafios para nossas teorias e práticas de formação:

Precisamos operar com uma nova epistemologia da formação (NÓVOA, 1995) que situe o desenvolvimento pessoal e profissional dos professores ao longo dos diferentes momentos de sua vida. Nossos processos formativos acontecem em lugares e tempos diferenciados, tendo a memória um trabalho privilegiado em reconstruí-los como recordações-referências constitutivas das narrativas de formação (JOSSO, 2004). Essa concepção implica, portanto, que se examine, de um lado, a história de vida e da formação intelectual dos professores em seus vários aspectos e fases (da infância à vida adulta) e, de outro lado, que se considere que tanto os professores como os futuros mestres são os agentes principais desse processo. Seguimos nessa direção, ao tomarmos a formação de Girassol, Amor-Perfeito e Orquídea em sua diacronia, desde suas experiências escolares até a aproximação (ou realização) da aposentadoria. Suas narrativas demonstram como a escolha e posterior itinerário na carreira profissional atrela-se às suas histórias de vida. Entender a formação conforme essa nova epistemologia formativa significa compreender os professores como pessoas e profissionais cujas vidas e trabalhos se modelam mutuamente. Silenciar a relação entre ambos, de modo contrário, não nos levará muito longe na compreensão do processo de formação profissional.

- Mesmo reconhecendo os inúmeros avanços na formação inicial e continuada de professores de educação física, ainda predominam tendências "escolarizadas" e "academicistas" dos programas de formação de professores dessa disciplina. Permanece, assim, o desafio da construção de teorias formativas que rompam com essa lógica na formação dos adultos em direção a metodologias e práticas de formação sensíveis ao professor como pessoa: da formação dos sujeitos aos sujeitos em formação. O emprego de abordagens (auto)biográficas, ao constituírem os professores como sujeitos de sua própria formação,

Movimento, Porto Alegre, v. 15, n. 02, p. 141-165, abril/junho de 2009. 
com trajetórias profissionais em um estágio de desenvolvimento determinado, abre uma via de acesso às experiências trazidas pelos (futuros) docentes, passíveis de serem problematizadas, desconstruídas ou construídas a partir de dimensões simbólicas distintas daquelas dos saberes da formação. Essas experiências cumprem um papel crucial na formação docente, pois a diversidade de expectativas que deságuam nessa fase da vida em formação nos alerta para o fato de que esta não deveria se construir, única e exclusivamente, por meio de cursos, com a aquisição de técnicas ou de conhecimentos livrescos (saberes da formação), mas também por meio de um intenso trabalho de (re-)elaboração das experiências e identidades pessoais, que são anteriores à entrada no ensino superior (NÓVOA, 1988).

- Ao confiar sua formação aos outros, os especialistas ou teóricos que lhe dizem como fazer, a voz do professor é silenciada nas decisões que precisam ser tomadas rumo a práticas renovadas. A formação, assim compreendida, dá a entender que: a) o problema é do professorado, e não da proposta de mudança; b) toda a questão é convencer o professor da bondade da mudança, superando a aversão inicial; c) silenciam-se as limitações internas das ações coercitivas da administração educativa para impor soluções "racionais", em grande parte concebidas em gabinetes ou em centros universitários, à margem de sua incidência nas vidas dos docentes. $\mathrm{O}$ valor formativo de uma ação educativa nos parece, ao contrário, mais ligado à dinâmica interna e à história de vida dos participantes do que à clareza das intenções do formador ou à qualidade de sua intervenção. O reconhecimento da pessoa que é o professor, com suas respectivas práticas ou estágio da carreira em que se encontra, contribui para entender como os docentes em formação assimilam e reinterpretam novas ideias e conteúdos, mas também implementam inovações e estratégias de ensino. Esse entrelaçamento entre o pessoal e o institucional, por consequência, aponta na direção de se conceber as reformas de maneiras mais "brandas" e menos vorazes sobre a vida dos professores, alunos e demais atores da escola, e a necessidade de ouvir mais os depoimentos desses atores e agentes (BOLÍVAR, 2002).

- Prestar atenção à voz do professor implica uma "humildade epistemológica" altamente desejável, sobretudo se considerarmos

Movimento, Porto Alegre, v. 15, n. 02, p. 141-165, abril/junho de 2009. 
que, até há bem pouco tempo, as teorias formativas estavam muito mais preocupadas em normatizar sobre as características que deveria reunir um bom professor (o professor crítico, o revolucionário, o progressista) ao invés de analisar o próprio movimento cotidiano e situado em que os professores produziam suas práticas, mas, também, tinham suas vidas produzidas por ela. Nessas situações, como apontou Fontana (2005), é como se o cotidiano e a vida do professor correspondessem à negação do projeto de sociedade visado pelos formadores. O resultado dessa legislação sobre os modos de dizer o "ser professor" pode ser visto na inadequação dos recentes avanços teóricos alcançados pela educação física brasileira e sua dificuldade de se materializar, em igual proporção, na intervenção pedagógica.

- Imputar aos professores o fracasso, o desânimo ou o conservadorismo obstrucionista no ensino não é a estratégia mais adequada quando se parte do pressuposto segundo o qual a biografia do professor é peça fundamental para se compreender os processos de ensino. Somente tomando conhecimento, desde um ponto de vista biográfico e institucional, do quadro que provoca o desinvestimento ou o abandono da docência, bem como das tentativas ensaiadas pelos professores para (sobre)viver no trabalho, é que podemos esboçar uma compreensão dos motivos de o docente transformar-se em um "professorbola". Apenas dessa maneira evitaremos a culpabilização daqueles que, em muitas ocasiões, são as verdadeiras vítimas. Nesses casos, não podemos exigir dos professores, parafraseando a sentença certeira de Beck (1997), soluções biográficas para contradições sistêmicas.

$$
\begin{aligned}
& \text { The Life of Physical Education Teachers: personal } \\
& \text { and professional teaching experience } \\
& \text { Abstract: This article deals with the life cycle of three } \\
& \text { Physical Education teachers in school context, using } \\
& \text { an analysis which combines biographical elements } \\
& \text { with professional career. It examines issues related } \\
& \text { to teachers training from their own school experiences } \\
& \text { in their childhood and adolescence to their late profes- } \\
& \text { sional path in Physical Education. At last it indicates } \\
& \text { some consideration for teacher training. } \\
& \text { Keywords: Biographic as topic. Faculty: history. } \\
& \text { Professional practice. Physical Education. }
\end{aligned}
$$

Movimento, Porto Alegre, v. 15, n. 02, p. 141-165, abril/junho de 2009. 


Vida de Professores de Educación Física: el
personal y el profesional en el ejercício de la
docência
Resumen: El artículo trata del ciclo de vida de tres pro-
fesoras de educación física en la escuela, combinando
elementos biográficos y profesionales. Son investigadas
cuestiones que se refieren a la formación de profesores,
desde sus experiencias profesionales en al infancia
e juventud hasta la posterior trayectoria profesional
en educación física. El trabajo se finaliza apuntando
consecuencias para la formación docente.
Palabras-claves: Biografia como asunto. Docentes:
Historia. Práctica profesional. Educación física.

\section{REFERÊNCIAS}

ALMEIDA, Luciano de; FENSTERSEIFER, Paulo Evaldo. Professoras de educação física: duas histórias, um só destino. Movimento, Porto Alegre, v.1 3, n. 2, p. 13-35, maio/ago. 2007.

BECK, Ulrich. A reinvenção da política: rumo a uma teoria da modernização reflexiva. In: BECK, Ulrich.; GIDDENS, Anthony.; LASH, Scott. (Org.). Modernização reflexiva. São Paulo: Unesp, 1997. p. 11-71.

BOLÍVAR, Antonio. Profissão professor: o itinerário profissional e a construção da escola. Tradução de Gilson César Cardoso de Souza. Bauru, SP: EDUSC, 2002.

BORGES, Cecilia Maria Ferreira. O professor de educação física e a construção do saber. Campinas: Papirus, 1998.

BRACHT, Valter. Educação física escolar: entre práticas inovadoras e o desinvestimento pedagógico.Vitória, 2007. 13p. Trabalho não publicado.

BRACHT, Valter et al. Pesquisa em ação: educação física na escola. ljuí: Unijuí, 2003.

BUENO, Belmira Oliveira et al. Histórias de vida e autobiografias na formação de professores e profissão docente (Brasil, 1985-2003). Educação e Pesquisa, São Paulo, v. 32, n. 2, p. 385-410, maio/ago. 2006.

BUENO, Belmira Oliveira. O método autobiográfico e os estudos com história de vida de professores: a questão da subjetividade. Educação e Pesquisa, São Paulo, v. 28, n. 1, p. 11-30, jan./jun. 2002.

CAPARROZ, Francisco Eduardo; BRACHT, Valter. O tempo e o lugar de uma didática da educação física. Revista Brasileira de Ciências do Esporte, Campinas, v. 28, n. 2, p. 21-37, jan. 2007.

CODO, Wanderley. Educação: carinho e trabalho. Brasília: Vozes, 1999.

Movimento, Porto Alegre, v. 15, n. 02, p. 141-165, abril/junho de 2009. 
ESTEVE, José Manuel. Mudanças sociais e função docente. In: NÓVOA, António. Profissão professor. Tradução de Irene Lima Mendes, Regina Correia, Luísa Santos Gil. 2. ed. Porto: Porto Editora, LDA, 1995. p. 93- 124.

O mal-estar docente: a sala-de-aula e a saúde dos professores. Tradução de Durley de Carvalho Cavicchia. Bauru: EDUSC, 1999.

FIGUEIREDO, Zenólia Cristina. Formação docente em educação física: experiências sociais e relação com o saber. Movimento, Porto Alegre, v. 10, n. 1, p. 89-111. jan./abr. 2004.

FONTANA, R. A. C. Como nos tornamos professoras? Belo Horizonte: Autêntica, 2005.

GONÇALVES, José Alberto. A carreira das professoras do ensino primário. In: NÓVOA, António. Vidas de professores. Tradução de Maria dos Anjos Caseiro, Manuel Figueiredo Ferreira. 2. ed. Porto: Porto Editora, LDA, 1995. p. 141-169.

GONZÁLEZ, Fernando Jaime; FENSTERSEIFER, Paulo Evaldo. Educação Física e cultura escolar: critérios para identificação do abandono do trabalho docente. In: CONGRESSO SUL-BRASILEIRO DE CIÊNCIAS DO ESPORTE, 3, 2006, Santa Maria. Anais... Santa Maria: CBCE, 2006. v. 1, p. 1-9.

GOODSON, Ivor. Dar voz ao professor: as histórias de vida dos professores e o seu desenvolvimento profissional. In: NÓVOA, António. Vidas de professores. Tradução de Maria dos Anjos Caseiro, Manuel Figueiredo Ferreira. 2. ed. Porto: Porto Editora, LDA, 1995. p. 63-78.

HUBERMAN, Michael. O ciclo de vida profissional dos professores. In: NÓVOA, António. Vidas de professores. Tradução Maria dos Anjos Caseiro, Manuel Figueiredo Ferreira. 2. ed. Porto: Porto Editora, LDA, 1995. p. 31-61.

JOSSO, Marie-Christine. Experiências de vida e formação. São Paulo: Cortez, 2004.

LAPO, Flavinês.; BUENO, Belmira Oliveira. Professores, desencanto com a profissão e abandono do magistério. Cadernos de Pesquisa, São Paulo, n. 118, p. 65-88, mar. 2003.

MOLINA NETO, V. et al. Pesquisar exige interrogar-se: a narrativa como estratégia de pesquisa e de formação do(a) pesquisador(a). Movimento, Porto Alegre, v. 12, n. 2, p. 9-33, maio/ago. 2006.

MORGADO, José Carlos. Currículo e profissionalidade docente. Porto: Editora Porto, 2005.

MUÑOZ PALAFOX, Gabriel Humberto. PCTP: por que está sendo difícil implementar propostas críticas de ensino da Educação Física na escola? In: MUÑOZ PALAFOX, Gabriel Humberto et al. (Org.). Planejamento coletivo do trabalho pedagógico - PCTP: a experiência de Uberlândia. 2. ed. Uberlândia: Casa do livro; Linograf, 2002. p. 11-24.

Movimento, Porto Alegre, v. 15, n. 02, p. 141-165, abril/junho de 2009. 
NÓVOA, António; FINGER, Mathias. 0 método (auto)biográfico e a formação. Lisboa: MS/DRHS/CFAP, 1988.

NÓVOA, António. Formação de professores e profissão docente. In: Os professores e sua formação. Tradução de Graça Cunha, Cândida Hespanha, Conceição Afonso e José António Sousa Tavares. 3. ed. Porto: Porto Editora, 1997. p. 15-33.

Os professores e as histórias da sua vida. In: (Org.). Vidas de professores. Tradução de Maria dos Anjos Caseiro, Manuel Figueiredo Ferreira. 2. ed. Porto: Porto Editora, LDA, 1995.

SANTINI, Joares et al. O processo de abandono da carreira docente dos professores de educação física da rede municipal de ensino de Porto Alegre: a síndrome do esgotamento profissional (SEP). Um estudo introdutório In: CONGRESSO BRASILEIRO DE CIÊNCIAS DO ESPORTE, 13, 2003, Caxambu. Anais... Caxambu: CONBRACE , 2003. p. 1-8.

SANTINI, Joarez et al. A síndrome do esgotamento profissional: O abandono da carreira docente dos professores de Educação Física da rede municipal de ensino de Porto Alegre. In: CONGRESSO INTERNACIONAL DE CIÊNCIAS DO ESPORTE, 1; CONGRESSO BRASILEIRO DE CIÊNCIAS DO ESPORTE, 4, 2005. Anais... Porto Alegre: CONICE, CONBRACE, 2005. p. 1634-1646.

SANTINI, Joarez. Síndrome do esgotamento profissional: revisão bibliográfica. Movimento, Porto Alegre, v. 10, n. 1, p. 183-209, jan./abr. 2004.

SANTINI, Joarez.; MOLINA NETO, Vicente. A síndrome do esgotamento em professores de educação física: um estudo na rede municipal de ensino de Porto Alegre. Revista Brasileira de Educação Física e Esportes, São Paulo, v. 19, n. 3, p. 209-222, jul./set. 2005.

SOUZA, Elizeu Clementino de. História de vida e formação de professores: um olhar sobre a singularidade das narrativas (auto)biográficas. In: MACEDO, Roberto Sidney (Org.). Currículo e docência: tensões contemporâneas interfaces pósformais. Salvador: Editora da UNEB, 2003, pp. 35-56.

TARDIF, Maurice. Saberes profissionais dos professores e conhecimentos universitários: elementos para uma epistemologia da prática profissional dos professores e suas consequências em relação à formação para o magistério. Revista Brasileira de Educação, São Paulo, n. 13, p. 5-24, 2000.

Recebido em: 14.03. 2008

Aprovado em: 16.02.2009

Movimento, Porto Alegre, v. 15, n. 02, p. 141-165, abril/junho de 2009. 